\title{
Deadly occupations: Assessing tuberculosis and accidental mortality among male workers in Sydney and Glace Bay, Nova Scotia, 1909-1917
}

\author{
Natalie C. Ludlow \\ Department of Geography and Planning, University of Saskatchewan \\ natalie.ludlow@usask.ca \\ Stacie D.A. Burke \\ Department of Anthropology, University of Manitoba
}

\begin{abstract}
This study examines associations between occupation and cause of death among 802 working-age males (15 to 64 years of age) who died in two single-industry communities (Glace Bay and Sydney) in Nova Scotia between 1909 and 1917. Employment in mining and steel manufacturing is assessed for cause-specific mortality among men who died in Canada's early industrial era, with a particular focus on deaths due to tuberculosis ( $n=140$, or $18 \%$ of deaths) and accidents $(n=225$, or $28 \%$ of deaths). Factoring in the effects of occupation, age at death, birthplace, community, and marital status, logistic regression results indicate that, among the men who died, occupation is a significant predictor for accidental deaths (relative to all other causes of death) but not for tuberculosis-related deaths. Interpretation of these results is grounded in a broader perspective on the nature of living and working conditions in these two single-industry communities.
\end{abstract}

Keywords: coal mining; steel manufacturing; tuberculosis; accidents; cause of death; company towns; single-industry communities; industrialization.

\section{Résumé}

Cette étude examine la relation entre l'activité et la cause de décès de 802 travailleurs masculins âgés de 15 à 64 ans de deux communautés à industrie unique (Glace Bay et Sydney) en Nowvelle-Écosse entre 1909 et 1917. Les emplois dans le secteur minier et de l'acier font l'objet d'une évaluation pour cause de mortalité chę les hommes décédés au début de l'ère industrielle au Canada et ciblent tout particulièrement les décès causés par la tuberculose ( $n=140$ on $18 \%$ des décès) et les accidents ( $n=225$ on $28 \%$ des décès). Si l'on tient compte de l'effet de l'activité, de l'âge au moment du décès, du lieu de naissance, de la communauté, de la situation de famille, les résultats de la régression logistique indiquent que pour les hommes qui sont morts, l'activité est une importante variable explicative de morts accidentelles (par rapport aux autres causes de décès), sauf dans le cas des décès causés par la tuberculose. L'interprétation de ces résultats s'inscrit dans une perspective plus grande de la nature de la vie et des conditions de travail de ces deux communautés à industrie unique.

Mots-clés : charbonnage, fabrication de l'acier, tuberculose, accidents, cause de décès, villes de compagnies, villes à industrie unique, industrialisation.

\section{Introduction}

Industrialization brought about significant changes to the landscape, as company-dominated, single-industry communities emerged in the 1830s (Porteous 1970; Garner 1992). While the specifics of company towns varied depending on the materials mined or produced, the degree of company control, and the social constructs altering 
demographic and social realities, there were some commonalities (Bulmer 1975; Frank 1981; Godoy 1985; Heyman 1995; Knapp and Pigott 1997; Ballard and Banks 2003). First, most companies facilitated general operations in community life by providing housing for workers (Fishback 1992). Company housing, however, was often stigmatized for its poor quality and problems of class conflict, due to the ever-present control of the company in both the workplace and the home (Porteous 1970; Mellor 1983; Robson 1984; Mulrooney 1991; Fishback 1992). For example, miners threatening strike action in both Pennsylvania and Cape Breton lost their homes because they were no longer considered to be "employed by the company" (Mellor 1983; Fishback 1992).

A second fundamental relates to the immense population growth realized in the initial development of industry towns, usually located in isolated, resource-specific geographic sites (Bulmer 1975; Godoy 1985; Fishback 1992; Heyman 1995). The isolation often intensified company control over workers, leading to exploitation of labourers, particularly immigrant labourers (Bulmer 1975; Avery 1979; Frank 1981; Godoy 1985; Heron 1988; Heyman 1995; Ballard and Banks 2003). The industrial-era influx of workers turned many small villages into large bustling cities (Garner 1992). According to Pelletier, Légaré, and Bourbeau (1997), industrialization amplified mortality burdens as population increases strained municipal infrastructure, including sanitation and water supply. Thus, irrespective of the specifics of the work environment, the very nature of early company towns likely impacted overall patterns of morbidity and mortality.

In this study, we examine the mortality profiles of working-age men (15-64 years of age) who died in two Nova Scotian communities in the years between 1909 and 1917. The communities of Glace Bay and Sydney are located on the island of Cape Breton, separated by a distance of approximately 20 kilometers. Historically, both communities dealt with coal. Glace Bay was the largest coal mining community along the Cape Breton coalfield. While Glace Bay miners extracted coal from underground mines located along the coastline and below the sea bed (Whitbeck 1914), factory workers in neighbouring Sydney refined that coal in the production of steel. In this way, an economy once grounded in fisheries quickly became Nova Scotia's industrial hub (Frank 1981; Millward 1993; Davey and Mackinnon 2001). In the early 20th century, both communities were under the influence of two companies operated by a single industrial giant, the Dominion Coal Company (DOMCO) and the Dominion Iron \& Steel Company (DISCO).

According to published census returns, Glace Bay and Sydney were comparable in terms of population size and industry-driven population growth, particularly acute between 1890 and 1910 (Frank 1981). Between 1901 and 1911, the population of Glace Bay swelled from 6,945 to 16,556. Likewise, the population of Sydney grew from 9,909 in 1901 to 17,185 in 1911. Employment opportunities in the mines at Glace Bay and the steel mills in Sydney attracted newcomers from Nova Scotia and beyond. Published census returns for 1911 characterize the skewed sex ratios and occupational focus of these single-industry communities. Working-age sex ratios (among those 15 to 64 years of age) revealed an excess of males in both Sydney and Glace Bay, with 139.3 and 126.5 working age males per 100 working age females, respectively. The 1911 census tabulations demonstrate an occupational structure favouring industrial employment; in Sydney 60.5\% (n=3,939) of men 15 to 64 years of age worked in manufacturing, while in Glace Bay $70.3 \%(\mathrm{n}=3,722)$ of men 15 to 64 years of age worked in the mining industry. Community infrastructure, water supply, and sanitation would suffer due to local population increases. Chronic housing shortages accompanied the initial period of industrial development, and overcrowded and temporary accommodations such as shacks and shanties were commonplace (McLeod 1909; Mellor 1983). Boarding houses established a system of bed sharing for men working opposite shifts (Mellor 1983). Both communities had fair water supplies, though there were problems with sewer contamination. In our sample, for example, we noted 26 cases of typhoid fever deaths $(13$ cases occurring in each community) occurring among the working-age men who died between 1909 and 1917.

We are interested in exploring the associations between cause-specific mortality and industrial occupations. In terms of human suffering, occupational injuries and disease place a heavy burden on society (Steenland et al. 2003). Historically, the hazardous work environments associated with mining and factory work fuelled accident-related morbidity and mortality to epidemic proportions. During the 1950s, for example, it was rare to have a week go by in Cape Breton when no miner was seriously injured or killed (Davey and Mackinnon 2001), despite the fact that mining conditions had improved significantly over the early 20th century with better air quality, lighting, and machinery (McIntosh 2000). Risk management procedures have become a priority, while in the past miners were considered "a dime a dozen" and more attention was perhaps given to production and profit than safety (Nova Scotia Department of Mines 1881; Mellor 1983). Chronic exposure to dust, fumes, and toxins were hazards common to mining and factory operations, creating a predisposition for respiratory problems (Fitch 1969; Lloyd 1971; Redmond et al. 1975; Coggon and Inskip 1994).

We question how workplace hazards may have differentially impacted miners and steel plant workers, and industrial and non-industrial workers more generally, through a comparative evaluation of cause-specific mortality 
profiles for working-age men who died. Due to hazardous working conditions in high-risk settings, accidental deaths are expected to have exerted a heavy impact on the mortality profiles of both miners and steel plant workers. Poor environmental conditions are targeted as a risk for compromised respiratory function and, possibly, increased susceptibility to tuberculosis, an endemic infectious disease in early 20th century Canada (Grzybowski and Allen 1999). We question whether those men working in the mining and steel manufacturing industries suffered greater risks of dying from accidents and tuberculosis relative to non-industrial workers. To explore this question, we use logistic regression analyses to explore predictors for cause-specific mortality among working-age men who died in Sydney and Glace Bay between 1909 and 1917.

\section{Accidental mortality}

Glace Bay, along with many other small coal towns in Cape Breton County, was vulnerable to the hazards of coal mining. Many factors contribute to high levels of risk associated with coal mining, including mine size, design, and condition, stability of the terrain, the mining company's policies and procedures, available technology and work conditions, and the age of the workforce (Hopkins and Palser 1987: 27). The type of underground mining practiced by the Glace Bay miners presented greater risks for accidents than above-ground work (Blank et al. 1995). Hopkins and Palser (1987: 27) note that coal mining was "inherently a dangerous business" due to the constant threat of methane gas explosions and roof falls resulting in the collapse of shafts. For Cape Breton County, "fall of stone," "fall of coal," and "fall of roof" were common accidents reported in cases of mining fatalities (Nova Scotia House of Assembly 1910-17). Methane gas, composed of carbon and hydrogen, is lighter than air, colourless, odorless, and it was highly poisonous and flammable (MacKenzie 2004). Inhalation of methane gas was another exposure risk. Cape Breton miners report inhaled methane gas to be a silent "gentle killer;" however, an explosion of methane gas made "the mine tunnels like the inside of a huge discharging shotgun, killing everyone in its path" (MacKenzie 2004: 11). Historically, many workplace decisions were left to miners because company focus on production and profit interfered with the hiring of mine officials to govern safety matters (Whitfield 1954; Fishback 1983).

Language barriers and the level of independence accorded to potentially minimally trained miners of the early 20th century would only serve to further the risks of mining accidents (Fishback 1983; Heron 1988). Accidents in coal mines were also linked to the age of workers. The ability to cope with occupational demands is thought to diminish with age because of progressive weakening of physical and mental capacities (Laflamme and Blank 1996). According to Whitfield (1954), however, age differentials in accident risk may have also reflected workplace hierarchies, where young workers were likely assistants to older miners who, in turn, directed and supervised the work. Whitfield (1954) notes that it was only in the 1950s that training became an established prerequisite to mining, a reality not experienced by early 20th-century Glace Bay coal miners (Mellor 1983).

The early 20th-century steel manufacturing industry was rife with hazards and, according to Fitch (1969), accidents claimed a larger proportion of workers' lives than any other cause, including tuberculosis and pneumonia. Dangers could include gas explosions, burns from pouring molten metal or slag, crushing injuries associated with locomotives and wagons, and falls of heavy objects (Barreto et al. 1997). Burns could occur at various sites throughout the plant (Barreto et al. 1997: 603), but the coke ovens were particularly hazardous because of the potential for spillage of molten steel from ladles (Fitch 1969). At the blast furnace in Sydney, men sometimes fell into the large molten steel holding pits and were killed instantly (Caplan 2005). Prolonged exposure to excessive heat could cause heat exhaustion and heat cramps, increasing general susceptibility to injury and accidents (Fitch 1969; Barreto et al. 1997). Steelworkers throughout the plant were found to suffer the effects of dehydration, particularly in and around the high temperature open hearths (Fitch 1969).

Communication problems, due to either language barriers or the noisy environment, only increased the risk for accidents at the steel plant. For example, though English-speaking, plant workers from Newfoundland spoke a different dialect, which made effective communication with other workers difficult. As a result, and in combination with the already noisy atmosphere, Newfoundlanders were often singled out for causing accidents (Caplan 2005). Steel plants were so noisy that they often led to partial or slight deafness among steelworkers (Fitch 1969). The noise was also found to be linked to feelings of irritability, interfering with normal work functions, and consequently increasing the risk for injuries and accidents (Barreto et al. 1997). Steel plant workers were also exposed to numerous gases, vapours, dust, and fumes in the steel plant. Exposure on a regular basis could result in disorientation, feelings of drunkenness, 
memory loss, dizziness, headaches, and sleepiness (Robinson et al. 1988; Barreto et al. 1997). Additionally, dust and fumes cloud the environment, causing reduced visibility and compromising general safety (Barreto et al. 1997).

\section{Tuberculosis mortality}

Tuberculosis was a common, endemic infectious disease in 19th- and early 20th-century Canada. It is estimated that 1 in 5 Canadians suffered from tuberculosis in their lifetime at the turn of the 19th century (Long et al. 1999). Individuals suffering cavitary tuberculosis disease can shed tuberculosis bacteria in coughs and sneezes. Direct exposure to mucus droplets may result in contact infection, though droplets may also evaporate into smaller droplet nuclei that can become airborne (Jacobs and Eisenach 1993). Inhaled tuberculosis bacteria are brought deep into the lungs, where infection may ensue. It is believed that most Canadians would have experienced primary tuberculosis infection and disease early in life, as children, and often within the context of the family home (Elliott 1924). Primary disease is typically self-limited, as individual immune response captures live tuberculosis bacteria in granulomas and holds the infection in a latent state. The ability to continue to hold the infection in a latent state can vary over an individual's lifetime, such that changes in immune status may lead to the release of tuberculosis bacteria and reactivation disease. In the early 20th century, notable increases in cases of reactivation disease coincided with adolescence and young adulthood (Grzybowski and Marr 1963).

We conceptualize the conditions associated with mining and factory work as a risk for disease reactivation, not infection (though some workers may have been exposed to primary tuberculosis infection or reinfection within the context of ill-ventilated and crowded places of work). Workers in mines and factories were confronted with a number of hazards that could challenge normal lung and immune function. By virtue of their exposure to coal dust, coal miners were known to experience myriad pulmonary diseases, including chronic cough, chronic bronchitis, emphysema, and coal workers' pneumoconiosis or "black lung" (Reid 1972; Hedlund et al. 2006; McIvor and Johnston 2007). Black lung is characteristically specific to coal miners, due to the chronic inhalation of coal dust. The deterioration of lung function associated with black lung often increased the risk for airflow limitation, bronchitis, emphysema, pulmonary tuberculosis, and respiratory failure and death (Leathart 1972; Reid 1972; Mosquera et al. 1994; Ross and Murray 2004; McIvor and Johnston 2007). A study by Meijers and co-authors (1997) of Dutch coal miners found that cumulative exposure to coal dust increased the death rate due to coal workers' pneumoconiosis, tuberculosis, and chronic obstructive pulmonary disease. The full effects of black lung resulted from chronic dust inhalation over long periods of employment in the coal mines, the symptoms becoming progressively more evident among miners between 40 to 70 years of age (Leathart 1972; Reid 1972; McIvor and Johnston 2007). The lives of miners were often cut short, however, by accidents or other diseases, such that the full progression and effects of coal workers' pneumoconiosis were only observed in a fraction of miners (Leathart 1972).

When coal dust enters the lungs, the immune system triggers the work of phagocytic macrophages to contain and remove this foreign matter, but as coal dusts accumulate, adequate macrophage function can be compromised (Heppleston 1991). Because macrophages are key immune cells that play a critical role in mediating tuberculosis infection in the lung, any compromise in their effective functioning could increase the risk of tuberculosis disease reactivation and progression (Wallis and Ellner 1994).

Like miners, industrial steelworkers also encountered suboptimal working environments that could compromise normal lung function and increase the risk of tuberculosis reactivation. Coke ovens, open hearths, and blast furnaces were notably hazardous, with workers prone to a variety of respiratory problems, including chronic bronchitis, respiratory cancers, and tuberculosis (Fitch 1969; Dancy 1971; Lloyd 1971; O'Connor 1971; Smith 1971; Redmond et al. 1975; Rosenman 1979; Hutchinson et al. 1996; Corhay et al. 1998). An analysis of the 1900 American census suggested that $31 \%$ of all steelworker deaths were caused by tuberculosis (Hutchcroft 1911). Greenburg (1925) noted that steelworkers experienced an excessively high death rate from tuberculosis as a result of the dusty work conditions characteristic of foundries.

In one study, the respiratory cancer rates of coke oven workers was twice that of other steelworkers, owing to chemical exposures resulting from the conversion of coal to coke (Lloyd 1971). The process of coking purifies coal through excessive heating, which encourages the removal of absorbed gases (such as carbon monoxide, methane, nitrogen, oxygen, ammonia) and breakdown of compound materials (such as pyritic sulphide to hydrogen sulphide; Smith 1971). The coking industry began in the mid-1800s, and by the 1900s, an awareness of the dangers of coke 
emissions led to the development of holding cells (Dancy 1971). Holding cells were only marginally effective, however, as gases could escape and emissions continued to be problematic until the introduction of respirators in the 1960s (O’Connor 1971; Smith 1971).

Open hearths were used to melt pig iron, scrap steel, and limestone to produce the preliminary steel product, prior to the blast furnace stage (Herty and Gaines 1929; Redmond et al. 1975). Arduous labour, extreme temperatures, poor ventilation, and numerous chemicals (e.g., iron oxide) predisposed open hearth workers to respiratory and cardiovascular problems, such as respiratory cancers, high blood pressure, and heart disease (Redmond et al. 1975). In Hamilton, Ontario, a higher risk for lung cancer was associated with the melting of molten steel at open hearths (Finkelstein et al. 1991).

Like those workers at the open hearths, blast furnace workers were also exposed to excess heat, poor ventilation, and chemicals, once again presenting risks for lung cancer and other respiratory diseases (Hutchinson et al. 1996). As iron ore is smelted (heating and melting ore to produce metal), it releases carbon monoxide and can lead to carbon monoxide poisoning and chronic bronchitis amongst workers (Jones and Sinclair 1975; Hutchinson et al. 1996; Tremblay 2007). The dusty conditions of the blast furnace also increased the risk of chronic respiratory obstruction (Corhay et al. 1998).

Tremblay (2007: 730) hypothesizes that coal, "the workhorse of progress" and industrialization, and the air pollution caused by the combustion of coal can be linked to the incidence of tuberculosis in historic industrializing populations and present-day developing countries. In tracing tuberculosis incidence rates in Canada and the United States, he notes an association between declining tuberculosis incidence rates, declining coal consumption or employment in the coal industry, and rising use of electricity. In developing his hypothesis at the physiological level, Tremblay (2007) posits an adverse relationship between tuberculosis bacteria, carbon monoxide levels, and the effectiveness of macrophages. While Tremblay's hypothesis has significance for populations and environments more generally, his findings underscore the risks of steel factory workers, in particular, who were regularly exposed to highvolume toxic emissions of burning coal.

\section{Materials and methods}

Our study examines cause-specific mortality to evaluate the relationship between occupation and deaths due to accidents and tuberculosis in early 20th-century Cape Breton, Nova Scotia. Information on all working-age men (15-64 years of age) who died in Glace Bay and Sydney in the years between 1909 and 1917, a total of 981 deaths, was abstracted from the province of Nova Scotia death registries. Women are not included, since at this point in time, women (and children) were rarely, if ever, employed in factories or mines (Mellor 1983). The study begins in 1909, one year after the initiation of the government system of death registration (prior to this time, churches recorded deaths), and ends in 1917 to avoid the added influence of World War I- and Spanish influenza-related mortality. Variables extracted from the death registries for analysis include occupation at death, age at death, marital status at death, place of birth, community of residence (either Glace Bay or Sydney), and cause of death.

Of the 950 cases where cause of death could be classified, 126 (of 516) and 123 (of 434) accidental deaths were registered for Sydney and Glace Bay working-age men (15-64 years), respectively. Tuberculosis deaths were registered for another 114 and 65 men in Sydney and Glace Bay, respectively. According to published census returns for 1911, there were 6,525 and 5,293 men 15-64 years of age enumerated in Sydney and Glace Bay. Using these census estimates as the denominator or "population at risk of dying" in mortality rate calculations, we estimate the average accidental mortality rate for men who died in Sydney between 1909 and 1917 to be 214 deaths per 100,000, and 258 deaths per 100,000 in Glace Bay. Average tuberculosis mortality rates are calculated at 194 and 136 deaths per 100,000 in Sydney and Glace Bay, respectively. Clearly mortality due to accidents outweighs tuberculosis-related mortality, particularly in Glace Bay. Tuberculosis mortality rates are comparable to Canada's overall 1908 mortality rate of 165 deaths per 100,000 (Grzybowski and Allen 1999) and Nova Scotia's 1921 tuberculosis mortality rate of 134 deaths per 100,000 (Wherrett 1977). As with other historical studies, we view our calculated rates cautiously, perhaps less for precision and more as a guide or aid to interpreting overall mortality profiles (Pelletier et al. 1997; Sawchuk and Burke 2000). This is particularly important because the average mortality rates calculated (based on the number of deaths from 1909 to 1917 and a population at risk of dying determined through 1911 published census data) likely overestimate tuberculosis and accident-related mortality, since population growth after the 1911 census would have led to further population increases and therefore a larger number of men at risk of dying (i.e., a larger denominator in the mortality rate calculation). 
Studies examining mortality dynamics often employ calculations of cause-specific mortality rates where the number of deaths due to a particular cause (the numerator) are measured relative to the population at risk of dying (the denominator). Both historical and contemporary studies can be hampered, however, by a lack of information pertaining to the population at risk of dying. To face this challenge, other mortality-related measures have evolved, including the proportionate mortality ratio and the mortality odds ratio, which examine the relative proportion of deaths due to a given cause (or causes) in relation to "other" deaths in both "exposed" and "unexposed" individuals (Miettinen and Wang 1981). In the case of our study, "exposure" would relate to workplace exposures in mining or industrial occupations. In this instance, the evaluation of a specific cause of death and its relative distribution across groups (e.g., occupation groups) can be considered by grounding the observation in comparison to the distribution of other causes of death across those occupation groups. Miettinen and Wang (1981: 147) liken the analysis of the mortality odds ratio to a type of case-control study, noting "the totality of deaths from the cause of interest, combining the exposed and nonexposed domains, can be thought of as a case series; and all the 'other' deaths can be thought of as a reference series for the cases - if exposure is not a risk indicator for death from those 'other' causes." Adopting a multivariate approach to analysis using logistic regression, researchers can then compare the odds ratios for a particular cause of death or disease cluster with reference to a particular risk factor (or "exposure") of interest, while also controlling for other confounding variables (see, for example, Burke and Sawchuk 2003; Lee et al. 2003; Wray et al. 2008; Zaridze et al. 2009; Zierler et al 1986). When assessing mortality odds ratios, the entire study is conditioned on dying (i.e., all those individuals included in the analysis have died). A proportion of industrial workers will die of tuberculosis and accidents (the remaining proportion succumbing to "other" causes of death), and their distribution of $\mathrm{TB} /$ accidents and other causes of death is compared to the distribution of $\mathrm{TB} /$ accidents and other causes of death in non-industrial workers who died. While the mortality odds ratio is a relative measure that can be used to assess factors associated with a particular cause of death, the mortality odds ratio does not assess the overall impact of a disease in a population in the same manner as cause-specific mortality rates or standardized mortality ratios, because of the lack of information pertaining to the population at risk of dying. As a result, the mortality odds ratio cannot reveal in quantitative terms the overall impact of a disease in a community.

Logistic regression, on the other hand, is a suitable statistic for our study since it allows for the prediction of a bivariate categorical dependent variable (accidental death/all-other deaths; TB death/all-other deaths) in each analysis. As a multivariate statistic, logistic regression analysis allows us to include other confounding variables (age, marital status, birthplace, community). The aims of the regression modelling are modest, simply allowing us to test the significance of one factor (occupation), while factoring in the effects of other potentially important explanatory variables. The models are not intended to provide a comprehensive assessment of the determinants of tuberculosis or accident-related mortality in early 20th-century Nova Scotia-in part because it was not the intention of the study, and in part because of the limited nature of the data collected. There is no question that more complete models predicting for tuberculosis or accidental mortality would take into account other important factors such as nutrition, working conditions, and household crowding. As a result, the ambitions of the regression models are modest yet focused, to evaluate the relationship between occupation and tuberculosis and accident-related mortality among all working-age men who died in Sydney and Glace Bay between 1909 and 1917.

A total of 802 deaths were included in logistic regression analyses, the reduction in sample size due to missing or incomplete information for either the dependent or independent variables (see Table 1). Classification of causes of death in historic population studies can be problematic, since many causes of death registered in the early 20th century were symptomatic or otherwise vague, even despite the fact that a physician signed off on each of the deaths registered (Alter and Carmichael 1999; Kunitz 1999). The death registrations used in this study also predate the standardization of cause of death classifications, according to the International Classification of Diseases. To the benefit of this study, however, accidental causes of death would have been less ambiguous than other causes of death. We have classified all accidental deaths as "accidental," including those obviously industry-related (e.g., "accident in coal mine-rupture of spinal cord" or "fatal accident in scrap pit at steel co."), as well as those accidental deaths that are more ambiguous in the sense that they did not indicate the place where the accident took place (e.g., "burns" or "fracture of skull"). As a result, we may overestimate industry-related accidents with the inclusion of accidents occurring in everyday life. Similar to accidental deaths, there was likely some familiarity in recognizing the symptoms of tuberculosis, given the time period under study and the commonness of the disease. Haemoptysis (coughing or spitting up blood from the lungs), progressive weight loss, and persistent fever were perhaps the most recognizable symptoms of advanced tuberculosis disease. While the death records could include primary and secondary (i.e., con- 
Table 1: Categorical coding of variables for logistic regression analyses.

\begin{tabular}{|c|c|c|c|c|c|}
\hline \multirow[t]{2}{*}{ Variable } & \multirow[t]{2}{*}{ Coding } & \multicolumn{2}{|c|}{ Total sample } & \multicolumn{2}{|c|}{$\begin{array}{c}\text { Included in regression } \\
\text { analyses }^{\mathrm{b}}\end{array}$} \\
\hline & & Number & Percent & Number & Percent \\
\hline \multirow[t]{5}{*}{ Cause of Death } & Tuberculosis & 179 & 18.2 & 140 & 17.5 \\
\hline & Accident & 249 & 25.4 & 225 & 28.1 \\
\hline & All Other & 522 & 53.2 & 437 & 54.4 \\
\hline & Not recorded or Ill-Defined ${ }^{a}$ & 31 & 3.2 & & \\
\hline & Total & 981 & & 802 & \\
\hline \multirow[t]{6}{*}{ Occupation } & Miners & 234 & 23.9 & 219 & 27.3 \\
\hline & Labourers & 203 & 20.7 & 177 & 22.1 \\
\hline & Skilled Workers & 202 & 20.6 & 181 & 22.6 \\
\hline & Non-industrial Workers & 246 & 25.1 & 225 & 28.1 \\
\hline & Not recorded or not employed & 96 & 9.8 & & \\
\hline & Total & 981 & & 802 & \\
\hline Occupation + & Glace Bay miners & 234 & 23.9 & 219 & 27.3 \\
\hline \multirow[t]{7}{*}{ Community } & Glace Bay labourers + skilled workers & 114 & 11.6 & 108 & 13.5 \\
\hline & Sydney labourers & 166 & 16.9 & 143 & 17.8 \\
\hline & Sydney skilled workers & 125 & 12.7 & 107 & 13.3 \\
\hline & Glace Bay non-industrial workers & 80 & 8.2 & 76 & 9.5 \\
\hline & Sydney non-industrial workers & 166 & 16.9 & 149 & 18.6 \\
\hline & Missing information & 96 & 9.8 & & \\
\hline & Total & 981 & & 802 & \\
\hline \multirow[t]{4}{*}{ Age at Death } & Young Working Age (15-29 years) & 372 & 37.9 & 300 & 37.4 \\
\hline & Middle Working Age (30-49 years) & 380 & 38.7 & 325 & 40.5 \\
\hline & Older Working Age (50-64 years) & 229 & 23.3 & 177 & 22.1 \\
\hline & Total & 981 & & 802 & \\
\hline \multirow[t]{4}{*}{ Birthplace } & Nova Scotia & 466 & 47.5 & 394 & 49.1 \\
\hline & Outside of Nova Scotia & 473 & 48.2 & 408 & 50.9 \\
\hline & Not recorded & 42 & 4.3 & & \\
\hline & Total & 981 & & 802 & \\
\hline \multirow[t]{3}{*}{ Community } & Sydney & 534 & 54.4 & 399 & 49.8 \\
\hline & Glace Bay & 447 & 45.6 & 403 & 50.2 \\
\hline & Total & 981 & & 802 & \\
\hline \multirow[t]{4}{*}{ Marital Status } & Never Married & 409 & 41.7 & 338 & 42.1 \\
\hline & Married and Widowed & 526 & 53.6 & 464 & 57.9 \\
\hline & Not recorded & 46 & 4.7 & & \\
\hline & Total & 981 & & 802 & \\
\hline
\end{tabular}

a Ill-defined causes of death included causes of death such as "general debility" and "old age.'

${ }^{\mathrm{b}} \mathrm{A}$ total of 179 cases were not included in the regression analyses due to missing information on one or more of the dependent and independent variables.

tributing) causes of death, for the purposes of this study we considered only the primary cause of death. Complete separation can be problematic in logistic regression analyses. Complete separation occurs when one (or more) of the independent variables has an absolute relationship with the dependent variable (e.g., all men born outside of Nova Scotia died of tuberculosis). Crosstabs analyses exploring the relationships between the dependent (accidental deaths, tuberculosis deaths) and independent variables confirmed the absence of complete separation.

The Historical International Standard Classification of Occupation (HISCO) manual was consulted to classify occupations (Van Leeuwen et al. 2002). We collapsed the major groups in HISCO into four broad groups, including miners (27.3\%), industrial labourers (22.1\%), skilled tradesmen (22.6\%), and non-industrial workers (28.1\%; see Table 1). The "non-industrial" occupations include professional, technical, managerial, service, clerical, and subsistence occupations. Though each death record lists occupation at the time of death, place of work was not specifically identified. Since all the miners were from Glace Bay, they were readily identifiable, but based on an occupation classification alone, Sydney steelworkers were more difficult to differentiate. As a result, we constructed a composite independent variable that combines occupation and place of residence and includes Glace Bay miners (27.3\%), Glace Bay labourers and skilled tradesmen (13.5\%), Sydney labourers (17.8\%), Sydney skilled tradesmen (13.3\%), Glace Bay non-industrial workers $(9.5 \%)$, and Sydney non-industrial workers (18.6\%). In logistic regression analyses, it is advisable that numbers in categories of independent variables do not fall below 50 cases. Since there were only 34 labour- 
ers who died in Glace Bay, they were combined with skilled tradesmen $(\mathrm{n}=74)$ in a single category, representing an "industrial" occupation group that could be compared, along with miners $(\mathrm{n}=219)$, to non-industrial workers $(\mathrm{n}=76)$.

To assess the relative impact of accident-related or tuberculosis mortality, we compare the odds of dying due to accidents or tuberculosis to all other causes of death among industrial and non-industrial workers who died in Sydney and Glace Bay between 1909 and 1917. It is important to stress once again that the entire study is conditioned on dying from some cause, though our interest is to assess whether tuberculosis and accidents were differentially experienced or over-represented among miners and steelworkers in comparison to other non-industrial workers who died. While the odds ratios may tells us something about the greater or lesser likelihood of accident and tuberculosisrelated mortality among industrial and non-industrial workers, it is important to bear in mind that the regression results do not tell us anything of the true impact of these causes of death in Sydney and Glace Bay. While we have relied on the relatively unequivocal nature of accidental deaths and the familiarity with tuberculosis to perform these analyses, other causes of death are not, in a sense, as reliably classified. In the absence of routine autopsies and a standardized cause of death classification, we cannot be as rigorous in the vetting of "other deaths" as in contemporary studies (see, for example, Lee et al. 2003; Wray et al. 2008), and we are reluctant to remove deaths from the "other" deaths category, as recommended by Miettinen and Wang (1981). As a result, we caution that some causes of death with occupational relationships may have been inadvertently retained in the "other" deaths category.

Two different models were constructed to assess whether industrial occupations were significant predictors of accident- or tuberculosis-related mortality. The first model in each set includes occupation and community as separate independent variables. The problem with this approach is the inability to distinguish between industrial workers in Sydney versus Glace Bay. As a result, the second model removes occupation and community and instead uses the occupation + community composite independent variable. The $\chi^{2}$ model summaries confirmed that each model was improved with the inclusion of the independent variables. If the Nagelkerke $\mathrm{R}^{2}$ is accepted as an analogous statistic to linear regression's $\mathrm{R}^{2}$ (Burns and Burns 2009), then the independent variables in all four models explain approximately $11 \%$ of the variation in deaths due to accidents and tuberculosis versus all other causes of death.

\section{Results}

The logistic regression models consider various worker-related characteristics in association with the likelihood of dying due to accidental causes (Table 2) and tuberculosis (Table 3) versus all other causes of death among men who died. Occupation, age of the worker, marital status, place of birth, and community of work and residence were all included as independent variables or possible predictors of accidental and tuberculosis deaths. The logistic regression model for accidental deaths (Table 2, Model 1) suggests that, conditional on death, occupation is a significant predictor for accident-related fatalities among men in mining and skilled trades, both having over twice the odds of dying in an accident relative to men in non-industrial occupations (miners, $\mathrm{OR}=2.624, \mathrm{p}<.01$; skilled tradesmen, $\mathrm{OR}=2.240$, $\mathrm{p}<.01$ ). Community did not exert an effect, as no significant differences in the odds of accidental death were observed for workers who died in Sydney versus Glace Bay. The occupation+community composite (Table 2, Model 2) suggests that Glace Bay miners and Sydney skilled tradesmen, in particular, were vulnerable to accidental deaths, with odds ratios of $1.675(\mathrm{p}<.05)$ and $1.801(\mathrm{p}<.05)$, respectively. This suggests to us that specific occupations in the mines or in the steel plant had a stronger link to accidental deaths than being a worker in either Glace Bay or Sydney.

Outside of occupation, age and place of birth were also significant predictors for accidental deaths versus other causes of death. The models in Table 2 suggest that men who died young (15-29 years of age) had over 3 times the odds of dying because of an accident ( $O R=3.544, \mathrm{p}<.001)$ relative to men who died later in life (50-64 years of age). Among the deaths observed in this study, significantly higher odds of accidental death are also observed among men aged 30-49 years relative to men aged 50-64 years $(\mathrm{OR}=2.864, \mathrm{p}<.001)$. With respect to place of birth, men who were born outside of Nova Scotia had almost twice the odds of dying in an accident relative to Nova Scotian men $(\mathrm{OR}=1.829, \mathrm{p}<.01)$, conditional on dying. The marital status of male workers was not significantly associated with the odds of dying an accidental death, still conditional on dying.

According to the results in Table 3, Model 1, occupation did not exert an effect in predicting for tuberculosis deaths, industrial worker or not, but location did exert a significant effect for men working and dying in Sydney being more likely to die of tuberculosis $(\mathrm{OR}=1.823, \mathrm{p}<.05)$. The composite community+occupation variable in Table 3 , Model 2 suggests that men working and dying in Sydney were more likely to die of tuberculosis than men working 
Table 2. Logistic regression predicting for accidental mortality among men 15 to 64 years of age who died in Sydney and Glace Bay, 1909-1917.

\begin{tabular}{|c|c|c|c|c|c|c|}
\hline \multirow{2}{*}{ Independent Variables } & \multicolumn{3}{|c|}{ MODEL 1} & \multicolumn{3}{|c|}{ MODEL 2} \\
\hline & Coeff. & $\operatorname{Exp}(B)$ & S.E. & Coeff. & $\operatorname{Exp}(B)$ & S.E. \\
\hline \multicolumn{7}{|l|}{ Age at Death } \\
\hline $15-29$ years & $1.253 * * *$ & 3.502 & 298 & $1.265^{* * *}$ & 3.544 & .298 \\
\hline $\begin{array}{l}30-49 \text { years } \\
50-64 \text { years }^{\mathrm{R}}\end{array}$ & $1.060 * * *$ & 2.886 & .262 & $1.052 * * *$ & 2.864 & .262 \\
\hline \multicolumn{7}{|l|}{ Marital Status } \\
\hline $\begin{array}{l}\text { Never Married } \\
\text { Married \& Widowed }^{\mathrm{R}}\end{array}$ & -.181 & .835 & .203 & -.192 & .826 & .203 \\
\hline \multicolumn{7}{|l|}{ Birthplace } \\
\hline $\begin{array}{l}\text { Outside Nova Scotia } \\
\text { Nova Scotia }^{\mathrm{R}}\end{array}$ & $.653 * * *$ & 1.922 & .178 & $.604 * *$ & 1.829 & .176 \\
\hline \multicolumn{7}{|l|}{ Occupation } \\
\hline Miners & $.965^{* *}$ & 2.624 & .288 & & & \\
\hline Labourers & -.091 & .913 & 261 & & & \\
\hline $\begin{array}{l}\text { Skilled trades } \\
\text { Non-industrial }^{\mathrm{R}}\end{array}$ & $.806 * *$ & 2.240 & .242 & & & \\
\hline \multicolumn{7}{|l|}{ Community } \\
\hline $\begin{array}{l}\text { Sydney } \\
\text { Glace Bay }\end{array}$ & .349 & 1.418 & .234 & & & \\
\hline \multicolumn{7}{|l|}{ Occupation $*$ Community } \\
\hline Glace Bay miners & & & & $.516^{*}$ & 1.675 & .249 \\
\hline Glace Bay labourers+skilled trades & & & & .220 & 1.246 & .304 \\
\hline Sydney labourer & & & & -.159 & .853 & .286 \\
\hline Sydney skilled trades & & & & $.588^{*}$ & 1.801 & .288 \\
\hline $\begin{array}{l}\text { Glace Bay non-industrial } \\
\text { Sydney non-industrial }^{\mathrm{R}}\end{array}$ & & & & -.767 & .465 & .430 \\
\hline $\begin{array}{l}\text { Sample Size } \\
\text {-2LL }\end{array}$ & & & $\begin{array}{r}802 \\
3.289\end{array}$ & & & $\begin{array}{r}802 \\
886.499\end{array}$ \\
\hline
\end{tabular}

Notes: Coeff. $=$ Logistic Regression Coefficient, $\operatorname{Exp}(B)=$ Odds Ratio, S.E. $=$ Standard Error

Significance Levels: ${ }^{*} \mathrm{p}<0.05, * * \mathrm{p}<0.01, * * * \mathrm{p}<.0 .001 ; \mathrm{R}=$ reference category.

and dying in Glace Bay, and it does not appear to have been significant whether they were working an industrial occupation or not. Glace Bay miners and Glace Bay labourers and skilled tradesmen, on the other hand, were significantly less likely to die of tuberculosis than all workers in Sydney (though Sydney non-industrial workers are the reference group, not that there are no significant differences in the odds of tuberculosis mortality within the Sydney occupation groups (Glace Bay miners, $\mathrm{OR}=.404, \mathrm{p}<.01$; Glace Bay labourers and skilled tradesmen, $\mathrm{OR}=.472, \mathrm{p}<.05$ ). While Glace Bay non-industrial labourers do not show significantly different odds of tuberculosis deaths relative to Sydney non-industrial labourers, their regression coefficient does point in the same direction as other Glace Bay workers (Glace Bay non-industrial workers, $\mathrm{OR}=.500, \mathrm{p}=.07$ ). It may have been the case that Glace Bay miners or industrial workers debilitated by tuberculosis disease had, by necessity, moved into non-industrial occupations prior to their death, and therefore influence the mortality profile of non-industrial workers by inflating tuberculosis burdens in this occupation category.

Other significant predictors of tuberculosis mortality were evident in the regression analysis (Table 3). Age is a strong predictor for tuberculosis deaths. Our model indicates that young working-age men who died between age 15 and 29 years had 5 times the odds of dying due of tuberculosis than men who died between age 50 and 64 years (the reference group) (OR=5.462, $\mathrm{p}<.001)$. Men who died between 30 and 49 years of age had almost twice the odds of dying of tuberculosis $(\mathrm{OR}=1.950, \mathrm{p}<.05)$. These age-at-death-related findings reflect those reported in the literature, suggesting that late adolescence and young adulthood were vulnerable periods in the lifecourse for reactivation of underlying latent tuberculosis infection (Grzybowski and Marr 1963). The birthplace of men who died in Sydney and Glace Bay also serves as a useful predictor of tuberculosis mortality. The regression results suggest that men born in Nova Scotia had over twice the odds of dying because of tuberculosis than men born elsewhere $(\mathrm{OR}=2.220$, 
Table 3. Logistic regression predicting for tuberculosis mortality among men 15 to 64 years of age who died in Sydney and Glace Bay, 1909-1917.

\begin{tabular}{|c|c|c|c|c|c|c|}
\hline \multirow{2}{*}{ Independent Variables } & \multicolumn{3}{|c|}{ MODEL 1} & \multicolumn{3}{|c|}{ MODEL 2} \\
\hline & Coeff. & $\operatorname{Exp}(\mathrm{B})$ & S.E. & Coeff. & $\operatorname{Exp}(B)$ & S.E. \\
\hline \multicolumn{7}{|l|}{ Age at Death } \\
\hline 15-29 years & $1.695^{* * *}$ & 5.447 & .348 & $1.698^{* * *}$ & 5.462 & .348 \\
\hline $30-49$ years & $.663^{*}$ & 1.940 & .314 & $.668^{*}$ & 1.950 & .314 \\
\hline \multicolumn{7}{|l|}{$50-64$ years $^{\mathrm{R}}$} \\
\hline \multicolumn{7}{|l|}{ Marital Status } \\
\hline Never Married & -.286 & .751 & .242 & -.283 & .753 & .242 \\
\hline Married \& Widowed ${ }^{\mathrm{R}}$ & & & & & & \\
\hline \multicolumn{7}{|l|}{ Birthplace } \\
\hline Outside Nova Scotia & $.846^{* * * *}$ & 2.330 & .217 & $.798 * * *$ & 2.220 & .215 \\
\hline Nova Scotia ${ }^{R}$ & & & & & & \\
\hline \multicolumn{7}{|l|}{ Occupation } \\
\hline Miners & -.275 & .760 & .331 & & & \\
\hline Labourers & -.134 & .874 & .285 & & & \\
\hline Skilled trades & -.198 & .821 & .264 & & & \\
\hline \multicolumn{7}{|l|}{ Non-industrial $^{R}$} \\
\hline \multicolumn{7}{|l|}{ Community } \\
\hline Sydney & $.601 *$ & 1.823 & .257 & & & \\
\hline Glace Bay ${ }^{\mathrm{R}}$ & & & & & & \\
\hline \multicolumn{7}{|l|}{ Occupation $*$ Community } \\
\hline Glace Bay miners & & & & $-.908 * *$ & .404 & .294 \\
\hline Glace Bay labourers+skilled trades & & & & $-.751 *$ & .472 & .346 \\
\hline Sydney labourer & & & & -.324 & .723 & .322 \\
\hline Sydney skilled trades & & & & -.110 & .896 & .315 \\
\hline Glace Bay non-industrial & & & & $-.692^{\mathrm{a}}$ & .500 & .386 \\
\hline \multicolumn{7}{|l|}{ Sydney non-industrial ${ }^{\mathrm{R}}$} \\
\hline Sample Size & & & 802 & & & 802 \\
\hline$-2 \mathrm{LL}$ & & & 87.961 & & & 687.506 \\
\hline
\end{tabular}

Notes: Coeff.=Logistic Regression Coefficient, $\operatorname{Exp}(\mathrm{B})=$ Odds Ratio, S.E. $=$ Standard Error

Significance Levels: ${ }^{*} \mathrm{p}<0.05, * * \mathrm{p}<0.01, * * * \mathrm{p}<.0 .001 ; \mathrm{R}=$ reference category.

a) $\mathrm{p}=.073$

$\mathrm{p}<.001)$. The marital status of male workers who died was not significantly associated with the odds of dying due to tuberculosis. Since we have established that occupation is a risk for accidental deaths in these communities, following Miettinen and Wang's (1981) caution to remove known exposure-related causes of death from the "other" deaths comparison group, we undertook another logistic regression on tuberculosis deaths, excluding men who died from accidental causes from the "other" deaths comparison group (Table 4). The results of this analysis do not differ substantially from those results presented in Table 3.

\section{Discussion}

Assessing risks for specific causes of death in past populations can be challenging, particularly when information on the population at risk for dying is not available. When cause-specific mortality rates cannot be calculated, there are other, relative measures of mortality and exposure which can be assessed, such as the mortality odds ratio (Miettinen and Wang 1981). This study examines patterns of cause-specific mortality, notably accident-related and tuberculosis mortality, among working-age men who died in Glace Bay and Sydney in relation to their industrial and non-industrial employment at the time of their deaths. In assessing relative associations between cause-specific mortality and exposure to industrial working conditions, this study examines the likelihood of tuberculosis and accidental mortality among men who died according to their occupation and other factors, but does not (and cannot) assess the true quantitative mortality burdens in these occupation groups. Since the data upon which the analyses are grounded concern only men who died, we must stress that we are examining cause of death distributions only 
Table 4. Logistic regression predicting for tuberculosis mortality among men 15 to 64 years of age who died in Sydney and Glace Bay, 1909-1917 (accidental deaths excluded).

\begin{tabular}{|c|c|c|c|c|c|c|}
\hline \multirow{2}{*}{ Independent Variables } & \multicolumn{3}{|c|}{ MODEL 1} & \multicolumn{3}{|c|}{ MODEL 2} \\
\hline & Coeff. & $\operatorname{Exp}(B)$ & S.E. & Coeff. & $\operatorname{Exp}(\mathrm{B})$ & S.E. \\
\hline \multicolumn{7}{|l|}{ Age at Death } \\
\hline $15-29$ years & $2.244 * * *$ & 9.435 & .372 & $2.274 * * *$ & 9.719 & .374 \\
\hline $30-49$ years & $.935 * *$ & 2.547 & .320 & $.951 * *$ & 2.588 & .321 \\
\hline \multicolumn{7}{|l|}{$50-64$ years $^{\mathrm{R}}$} \\
\hline \multicolumn{7}{|l|}{ Marital Status } \\
\hline Never Married & -.468 & .627 & .270 & -.468 & .626 & .270 \\
\hline \multicolumn{7}{|l|}{ Married \& Widowed ${ }^{\mathrm{R}}$} \\
\hline \multicolumn{7}{|l|}{ Birthplace } \\
\hline Outside Nova Scotia & $.652^{* *}$ & 1.919 & .234 & $.618 * *$ & 1.855 & .231 \\
\hline \multicolumn{7}{|l|}{ Nova Scotia ${ }^{\mathrm{R}}$} \\
\hline \multicolumn{7}{|l|}{ Occupation } \\
\hline Miners & -.046 & .955 & .348 & & & \\
\hline Labourers & -.268 & .765 & .307 & & & \\
\hline Skilled trades & .102 & 1.107 & .287 & & & \\
\hline \multicolumn{7}{|l|}{ Non-industrial $^{\mathrm{R}}$} \\
\hline \multicolumn{7}{|l|}{ Community } \\
\hline Sydney & $.713 * *$ & 2.040 & .271 & & & \\
\hline \multicolumn{7}{|l|}{ Glace Bay ${ }^{\mathrm{R}}$} \\
\hline \multicolumn{7}{|l|}{ Occupation $*$ Community } \\
\hline Glace Bay miners & & & & $-.832 * *$ & .435 & .317 \\
\hline Glace Bay labourers+skilled trades & & & & -.681 & .506 & .366 \\
\hline Sydney labourer & & & & -.511 & .600 & .348 \\
\hline Sydney skilled trades & & & & .136 & 1.146 & .352 \\
\hline Glace Bay non-industrial & & & & $-.917^{*}$ & .400 & .403 \\
\hline \multicolumn{7}{|l|}{ Sydney non-industrial ${ }^{\mathrm{R}}$} \\
\hline Sample Size & & & 577 & & & 577 \\
\hline$-2 \mathrm{LL}$ & & & 73.244 & & & 570.814 \\
\hline
\end{tabular}

Notes: Coeff. $=$ Logistic Regression Coefficient, Exp(B)=Odds Ratio, S.E. $=$ Standard Error

Significance Levels: ${ }^{*} \mathrm{p}<0.05,{ }^{*} \mathrm{p}<0.01, * * * \mathrm{p}<.0 .001 ; \mathrm{R}=$ reference category.

among men who died, and we must not extend these findings to more specific conceptions of mortality risk (which is grounded in the numbers in the living population at risk of dying). We do not assess true mortality risk, but ask: Of all the working-age men from Sydney and Glace Bay who died between 1909 and 1917, were men in occupations such as mining and steel work more likely to have died of tuberculosis or accidents? As a result, we must be cautious in qualifying our findings, as they only applied to the men who died, and not the communities at large.

The results of the logistic regression indicate that, after controlling for other factors, industrial occupations are a significant predictor for accidental death but are not a significant predictor for tuberculosis mortality among the working-age men in Sydney and Glace Bay who died between 1909 and 1917. Given the harsh working conditions associated with steel factory work and mining, it was expected that there would be a relationship between occupation and accidental causes of death. In the past, in both industries, accidents claimed more lives than any other cause of death (Enterline 1964; Fitch 1969). This study has similar findings, since Glace Bay miners and skilled tradesmen in Sydney who died between 1909 and 1917 were found to have significantly higher odds of dying due to accidents relative to men in other occupation groups who died. General industrial labourers, however, did not, and this may have been because they had less contact with underground work in Glace Bay and less exposure to the internal factory hazards, particularly the blast furnaces, coke ovens, and open hearths in Sydney. Industrial labourers, most of whom were associated with the steel plant in Sydney, typically worked in the labour yards, bringing in supplies and carting away debris (Caplan 2005).

Accidents for these industries were routinely documented by the Nova Scotia House of Assembly (1910-17) and Dominion Iron and Steel Company (1893-1980), a testament to the overarching risks of employment in the mines and in the factories. Expenditures on health and safety were at the bottom of the company's financial priorities, and workers' unions were, until the 1920s, nonexistent (Mellor 1983). Vulnerable miners and steelworkers in Glace Bay 
and Sydney typically worked long twelve-hour shifts, often six and sometimes seven days a week (Mellor 1983; Heron 1988; Caplan 2005). The overall control exerted within the context of the company town likely created over-worked and exhausted employees, and elevated the risks of accidents.

The relationship observed between accidents and the age of men who died could be a factor of age-related occupational skills attainment. In a late 20th-century study of Brazilian steelworkers, for example, Barreto and co-authors (1996) found that young workers were disproportionately prone to injuries. Mekelburg (1952) also noted that young steelworkers were highly susceptible to accidents and injuries. Skills attained with age and experience could be a critical factor mitigating hazards in the workplace, particularly among those men working directly with chemicals and molten steel at the steel plant or working the more dangerous lower seams in coal mines (Heron 1988; Caplan 2005). Young workers typically gained skills through on-site apprenticeships, working first as helpers in mining and industry (Caplan 2005). Some coal mining studies, however, suggest that older miners were more susceptible to accidents and injury (see Whitfield 1954; Laflamme and Blank 1996). In the coal mines, although occupational hierarchy is less prevalent, more experienced miners were sometimes called upon to work and manage the lower seams where occupational hazards such as roof collapse or methane gas explosions were more pronounced. Young working-age males likely had less skill in their early years of employment, which may have arguably increased their exposure to dangerous situations or the potential to make mistakes, and, in turn, increased the frequency of accidents and fatalities.

The higher odds of accidental death occurring among workers born outside of Nova Scotia may be linked to language differences and barriers to effective communication, which have been found to increase the risk of industrial accidents (Avery 1979; Fishback 1983; Heron 1988; Caplan 2005). Other factors, such as skill and job status, may have also factored in, as foreign-born workers were typically given lower-paying and lower-status positions (Avery 1979; Heron 1988; Caplan 2005).

Interestingly, this study did not identify a significant association between occupation and tuberculosis among men who died between 1909 and 1917, a finding which runs contrary to those reported in the literature, given the hazards of coal dust for miners and toxic pollutant exposure among steelworkers (see, for example, Greenburg 1925; Hutchcroft 1911; Rockette 1977; Hautaniemi et al. 1999; MacKenzie 2004; McIvor and Johnston 2007; Tremblay 2007). Relative to accidental mortality, however, assessing the association between occupation and tuberculosis among men who died is more problematic. Tuberculosis disease typically follows a slow, chronic course of progression. In the meantime, as disease symptoms become more worrisome and debilitating, workers may change jobs, leave employment altogether, or move out of communities (particularly to more rural locales, where fresh air was equated with the promise of healing). As a result, there can be significant blurring of occupational links to tuberculosis mortality, even if industrial occupations increased the risk for disease progression or death. An additional obscuring of the occupation/tuberculosis link may ensue because of other acute causes of death, particularly accidents, which we know were common among industrial workers and could occur at any time-which might effectively remove from the population a worker who may have also been suffering tuberculosis, even in its earliest stages. In effect, accidents could claim the lives of workers who might otherwise have lived longer and died of tuberculosis. Although no significant association was found between occupation and tuberculosis mortality among the men who died, both the mining and factory work environments are still likely to have compromised lung function and led to increased susceptibility to the disease.

Past immigration policies in Canada may have influenced tuberculosis dynamics in these communities through federal screening and quarantine protocols (Gushulak and Williams 2004; Beiser 2005), and may help to explain the link between place of birth and tuberculosis mortality among the men who died. Many miners and steelworkers arriving in Glace Bay and Sydney were actively recruited by local company officials (Heron 1988), who would likely be looking for healthy robust men to work in these arduous occupations. These recruits, mostly from Europe, often came from rural communities, which may have had lower underlying tuberculosis burdens relative to large European cities (see Heron 1988; Woods and Hinde 1987; Luckin and Mooney 1997; Pelletier et al. 1997). Thus, the selection of healthy-looking recruits from rural areas could have lessened the tuberculosis burdens in non-native (foreign-born) workers.

Before the establishment of the Sydney steel plant, Glace Bay was Nova Scotia's largest community along the coalfield. With the rise of steelmaking, Sydney rapidly eclipsed Glace Bay and became a major urban centre on the island. Unhygienic, overcrowded, and unsanitary living conditions were common elements of urban living in the 19th and early 20th centuries, with links to tuberculosis risks (Condran and Crimmins-Gardner 1978; Woods and Hinde 1987; Gagan 1989; Barkin and Gentles 1990; Leavitt 1992; Pelletier et al. 1997). Stimulated by industrialization, Sydney's rapid urbanization would have amplified the presence of squatter-type settlements and overflowing boarding 
houses, in turn possibly increasing exposure to and transmission of tuberculosis. Although both communities expanded during the early 20th century and living conditions were mutually poor, Sydney's rapid growth from a sleepy town to a bustling urban centre likely caused more acute problems than Glace Bay's more gradual expansion.

The general vulnerability of older adolescents and young adults to tuberculosis disease reactivation may have been irritated by the generally poor standard of living common in early company towns such as Sydney and Glace Bay. Strains on housing and the presence of overcrowded boarding houses (occupied mostly by young single males) were problems in these and other single-industry communities (Fishback 1983; Mellor 1983; Robson 1984; Belshaw 1990; Mulrooney 1991; Ripmeester 1994; Caplan 2005), and often scrutinized in local public health reports (see Curry 1909; McDonald 1909; McLeod 1909; Green 1914, 1916; City Engineer 1917). These reports also noted the poor state of basic infrastructure existing under the strain of expanding populations. Late 19th-century mill workers in New England were found living under similarly precarious conditions (Hautaniemi et al. 1999). In the United States prior to 1925, tuberculosis mortality amongst steelworkers was highest among men aged 15 to 44 years, decreasing sharply thereafter (Greenburg 1925). In the Canadian industrial city of Hamilton, Ontario, the highest rates for tuberculosis were found in the densely populated production centres of the city (Gagan 1989).

\section{Conclusions}

Using cause-specific death registrations, the research explores aspects of cause-specific mortality among working-age men who died in two of Nova Scotia's single-industry communities. This particular type of community structure, found in both Sydney and Glace Bay, creates an economic peculiarity marked by substantial increases in industrial occupations (as reflected in the large percentage of men working in manufacturing and mining occupations, and the skewed sex ratios of the working-age populations in Sydney and Glace Bay) that, in turn, reshape susceptibilities to industry-related causes of death. Our study cannot assess actual occupation-specific mortality rates in these communities, however, and undoubtedly that analysis would tell a very different story about the impact of selected causes of death among industrial and non-industrial workers. Our study does, however, assess correlates of cause-specific mortality among men who died in these communities between 1909 and 1917. The high burden of accidental causes of death observed among the men who died likely reflects the dynamics of company town life around the turn of the 20th century, where greater attention was placed perhaps on the pecuniary aspects of industry, rather than on worker safety (Whitfield 1954; Fishback 1983; Mellor 1983). Advances in occupational health and safety, alongside the formation of industry-related unions in Nova Scotia in the 1920s, meant that such occupational risks would decline as the 20th century progressed. Although this study failed to demonstrate an association between tuberculosis and industrial occupations such as mining and steel manufacturing among the men who died, it is well understood that these industries, in particular, were associated with risks to healthy lung functioning. Since this study is situated close to the commencement of industry in these communities, the likelihood for observing late-onset chronic, occupation-related tuberculosis mortality may have been lower than would be the case in subsequent decades. Based on calculated accidental mortality rates, it is clear that accidents played a larger role in shaping the mortality profiles of these industrial communities than tuberculosis did. In effect, untimely accidents that disproportionately killed younger workers, immigrant workers, Glace Bay miners, and Sydney skilled tradesmen, in combination with other factors (such as changing jobs or leaving employment or the communities altogether), may have lead to distortions in the occupation and cause-of-death associations which were observed among the men who died, or may have even reshaped the deaths we did observe in the death registrations, if men left Sydney or Glace Bay prior to their deaths. These problems confound attempts to evaluate the linkage between occupation and a slow-progressing disease such as tuberculosis. Despite these difficulties, our study considers the ecological construct of early company towns and the potential for exploring linkages between occupation and mortality risks in these early 20th century populations.

\section{Acknowledgements}

The authors thank the journal's anonymous reviewers for their insightful comments, which substantially improved the final manuscript. We would also like to thank the Nova Scotia Archives and Records Management and the Beaton Institute Archives for their assistance in locating and obtaining records that made this research possible. 


\section{References}

Alter, G.C., and A.G. Carmichael. 1999. Classifying the dead: Towards a history of registration of causes of death. Journal of the History of Medicine 54:114-132.

Avery, D. 1979. Dangerous Foreigners: European Immigrant Workers and Labour Radicalism in Canada, 1896-1932. Toronto: McClelland and Stewart.

Ballard, C., and G. Banks. 2003. Resource wars: The anthropology of mining. Annual Review of Anthropology 32:287313.

Barkin, R., and I. Gentles. 1990. Death in Victorian Toronto, 1850-1899. Urban History Review 19:14-29.

Barreto, S.M., A.J. Swerdlow, P.G. Smith, and C.D. Higgins. 1996. Mortality from injuries and other causes in a cohort of 21,800 Brazilian steelworkers. Occupational and Environmental Medicine 53:343-350.

- 1997. A nested case-control study of fatal work related injuries among Brazilian steelworkers. Occupational and Environmental Medicine 54:599-604.

Beiser, M. 2005. The health of immigrant refugees in Canada. Canadian Journal of Public Health 96:30-44.

Belshaw, J. 1990. The standard of living of British miners on Vancouver Island, 1848-1900. BC Studies (Winter):37-64.

Blank, V.L.G., R. Andersson, A. Lindén, and B.C. Nilsson. 1995. Hidden accident rates and patterns in the Swedish mining industry due to involvement of contractor workers. Safety Science 21:23-35.

Bulmer, M.I.A. 1975. Sociological models of the mining community. Sociological Review 23:107-131.

Burke, S.D.A., and Sawchuk, L.A. 2003. Tuberculosis mortality and recent childbirth: A retrospective case-control study of Gibraltarian women, 1874-1884. Social Science and Medicine 56:477-490.

Burns, R., and R. Burns. 2009. Business Research Methods and Statistics using SPSS. London: Sage Publications Ltd. Companion website: www.uk.sagepub.com/burns/chapters.htm.

Caplan, R. 2005. Views from the Steel Plant: Voices and Photographs from 100 years of Making Steel in Cape Breton Island. Sydney, NS: Breton Books.

City Engineer. 1917. Annual Report of the City Engineer: City of Sydney. Sydney, NS: Annual Reports of the City of Sydney.

Coggon, D., and H. Inskip. 1994. Lobar pneumonia: An occupational disease in welders. The Lancet 344:4-5.

Condran, G.A., and E. Crimmins-Gardner. 1978. Public health measures and mortality in U.S. cities in the late nineteenth century. Human Ecology 6:27-54.

Corhay, J.L., T. Bury, R. Louis, J.P. Delavignette, J.M. Kayembe, G. Weber, A. Albert, and M.F. Radermecker. 1998. Bronchial responsiveness in active steelworkers. European Respiratory Journal 11:272-277.

Curry, A. 1909. Report of Sanitary Inspector: City of Sydney. Sydney, NS: Annual Reports of the City of Sydney.

Dancy, T.E. 1971. Control of coke oven emissions. Journal of Occupational Medicine 13:75-82.

Davey, W., and R. Mackinnon. 2001. Nicknaming patterns and traditions among Cape Breton coal miners. Acadiensis 30:71-83.

Dominion Company Papers. 1893-1980. Steel and Coal Operations, Operations of the General Office: Blast Furnace Operations, Records of Injuries. Bell Island, NL: Dominion Iron and Steel Company.

Elliott, J.H. 1924. The treatment of pulmonary tuberculosis. Canadian Practitioner 49:379-385.

Enterline, P.E. 1964. Mortality rates among coal miners. American Journal of Public Health 54:758-768. 
Finkelstein, M.M., Boulard, M., and Wilk, N. 1991. Increased risk of lung cancer in the mining department of a second Ontario steel manufacturer. American Journal of Industrial Medicine 19:183-194.

Fishback, P. 1983. Workplace safety during the progressive era: Fatal accidents in bituminous coal mining, 1912 1923. Explorations in Economic History 23:269-298.

. 1992. The economics of company housing: Historical perspectives for the coal fields. The Journal of Law Economics 8:346-365.

Fitch, J.A. 1969. The Steelworkers. Repr. edn. (1910). New York: Arno Press Inc.

Frank, D. 1981. Company town/labour town: Local government in the Cape Breton coal towns, 1917-1926. Social History 14:177-196.

Gagan, R. 1989. Mortality patterns and public health in Hamilton, Canada, 1900-1914. Urban History Review/Revue d'bistoire urbaine 17:161.

Garner, J.S. 1992. The Company Town: Architecture and Society in the Early Industrial Age. New York: Oxford University Press.

Godoy, R. 1985. Mining: Anthropological perspectives. Annual Review of Anthropology 14:199-217.

Green, F.W. 1914. Report of the Medical Health Officer: Town of Glace Bay. Glace Bay, NS: Annual Reports of the Town of Glace Bay.

-1916. Report of the Medical Officer: Town of Glace Bay. Glace Bay, NS: Annual Reports of the Town of Glace Bay.

Greenburg, L. 1925. Studies of the industrial dust problem: I. Dust inhalation and its relation to industrial tuberculosis. Public Health Reports (1896-1970) 40:291-309.

Grzybowski, S., and E.A. Allen. 1999. Tuberculosis: 2. History of the disease in Canada. Canadian Medical Association Journal 160:1025-1028.

Grzybowski, S., and W.B. Marr. 1963. The unchanging pattern of pulmonary tuberculosis. Canadian Medical Association Journal 89:737-740.

Gushulak, B.D., and L.S. Williams. 2004. National immigration health policy: Existing policy, changing needs, and future directions. Canadian Journal of Public Health 95:27-29.

Hautaniemi, S.I., A.C. Swedlund, and D.L. Anderton. 1999. Mill town mortality: Consequences of industrial growth in two nineteenth-century New England towns. Social Science History 23:1-39.

Hedlund, U., B. Järvholm, and B. Lundbäck. 2006. Persistence of respiratory symptoms in ex-underground iron ore miners. Occupational Medicine 56:380-385.

Heppleston, A.G. 1991. Minerals, fibrosis, and the lung. Environmental Health Perspectives 94:149-168.

Heron, C. 1988. Working in Steel: The Early Years in Canada, 1883-1935. Toronto: McClelland \& Stewart.

Herty, C. and J. Gaines. 1929. Oxides in Pig Iron: Their Origin and Action in the Steel-Making Process. Washington: Department of Commerce United States of America.

Heyman, J.M. 1995. In the shadow of the smokestacks: Labour and environmental conflict in a companydominated town, in Articulating Hidden Histories: Exploring the Influence of Eric R. Wolf, edited by J. Schneider and R. Rapp. Berkley, CA: University of California.

Hopkins, A., and J. Palser. 1987. The cause of coal mine disasters. Industrial Relations Journal 18:26-39.

Hutchcroft, L.W. 1911. Occupational statistics for tuberculosis in Wisconsin. Journal of the American Public Health Association 1:503-507. 
Hutchinson, P.A., H.A. Cowie, P.T. Donnan, J.F. Hurley, C.F. Taylor, and A. Pilkington. 1996. Mortality of British Steelworkers Over an Extended Follow-up Period. Historical Research Report. Edinburgh (UK): Institute of Occupational Medicine.

Jacobs, R.F., and K.D. Eisenach. 1993. Childhood tuberculosis. Advances in Pediatric Infectious Diseases 8:23-51.

Jones, J.G., and A. Sinclair. 1975. Arterial disease among blast furnace workers. Annals of Occupational Hygiene 18:15-20.

Knapp, A.B., and V. Pigott. 1997. The archaeology and anthropology of mining: Social approaches to an industrial past. Current Anthropology 38:300-304.

Kunitz, S.J. 1999. Premises, premises: Comments on the comparability of classifications. Journal of the History of Medicine 54:226-240.

Laflamme, L., and V.L.G. Blank. 1996. Age-related accident risks: Longitudinal study of Swedish iron ore miners. American Journal of Industrial Medicine 30:479-487.

Leathart, G.L. 1972. Clinical aspects of respiratory disease due to mining, in Medicine in the Mining Industries, editied by J.M. Rogan. London: William Heinemann Medical Books.

Leavitt, J.W. 1992. "Typhoid Mary” strikes back: Bacteriological theory and practice in early twentieth-century public health. ISIS 83:608-629.

Lee, L.J-H., C-W. Chung, Y-C. Ma et al. 2003. Increased mortality odds ratio of male liver cancer in a community contaminated by chlorinated hydrocarbons in groundwater. Occupational and Environmental Medicine 60:364-369.

Lloyd, W.J. 1971. Long-term mortality study of steelworkers: V. Respiratory cancer in coke plant workers. Journal of Occupational Medicine 13:53-68.

Long, R., H. Njoo, and E. Hershfield. 1999. Tuberculosis: 3. Epidemiology of the disease in Canada. Canadian Medical Association Journal 160:1185-1190.

Luckin, B., and G. Mooney. 1997. Urban history and historical epidemiology: The case of London, 1860-1920. Urban History 24:37-55.

MacKenzie, R. 2004. That Bloody Cape Breton Coal: Stories of Mining Disasters in Everyday Life. Wreck Cove, Cape Breton, NS: Breton Books.

McDonald, E.O. 1909. Report of the Medical Officer: Town of Glace Bay. Glace Bay, NS: Annual Reports of the Town of Glace Bay.

McIntosh, R. 2000. Boys in the Pits: Child Labour in Coal Mines. Quebec: McGill-Queen's University Press.

McIvor, A., and R. Johnston. 2007. Miners' Lung: A History of Dust Disease in British Coal Mining. Burlington, VT: Ashgate Publishing.

McLeod, J.K. 1909. Report of City Medical Officer: City of Sydney. Sydney, NS: Annual Reports of the City of Sydney.

Meijers, J.M.M., G.M.H. Swaen, and J.J.M. Slangen. 1997. Mortality of Dutch coal miners in relation to pneumoconiosis, chronic obstructive pulmonary disease, and lung function. Occupational and Environmental Medicine 54:708-713.

Mekelburg, J.A.A. 1952. Accident prevention in industry. Occupational Medicine 1:178-182.

Mellor, J. 1983. The Company Store: James Bryson McLachlan and the Cape Breton Coal Miners 1900-1925. Toronto: Doubleday Canada.

Millward, H. 1993. Mine operations and mining leases on Nova Scotia's Sydney Coalfield, 1720- the present. Nova Scotia Historical Review 13:67-86.

Miettinen, O.S., and J-D. Wang. 1981. An alternative to the proportionate mortality ratio. American Journal of Epidemiology 114:144-148. 
Mosquera, J.A., L. Rodrigo, and F. Gonzálvez. 1994. The evolution of pulmonary tuberculosis in coal miners in Asturias, Northern Spain: An attempt to reduce the rate over a 15-year period, 1971-1985. European Journal of Epidemiology 10:291-297.

Mulrooney, M.M. 1991. A legacy of coal: The coal company towns of Southern Pennsylvania. Perspectives in Vernacular Architecture 4:130-137.

Nova Scotia Department of Mines. 1881. Report of the Department of Mines, Nova Scotia for the Year 1881. Halifax: Commissioner of Public Works and Mines, Queen's Printer.

Nova Scotia House of Assembly. 1910-1917. Journals and Proceedings of the House of Assembly of the Province of Nova Scotia. Halifax: Nova Scotia Government Publication, Queen's Printer.

O’Connor, R.B. 1971. Improving health of coke oven workers. Journal of Occupational Medicine 13:83-85.

Pelletier, F., J. Légaré, and R. Bourbeau. 1997. Mortality in Quebec during the nineteenth century: From state to the cities. Population Studies 51:93-103.

Porteous, J.D. 1970. The nature of the company town. Transactions of the Institute of British Geographers 51:127-142.

Redmond, C.K., J. Gustin, and E. Kamon. 1975. Long-term mortality experience of steelworkers: VIII. Mortality patterns of open hearth steelworkers (A Preliminary Report). Journal of Occupational Medicine 17:40-43.

Reid, L. 1972. The pathology of coal pneumoconiosis, in Medicine in the Mining Industries, edited by J.M. Rogan. London: William Heinemann Medical Books.

Ripmeester, M. 1994. Mines, homes, and halls: Place and identity as a gold miner in Rossland, British Columbia 1898-1901. The Canadian Geographer 38:98-110.

Robinson, C.C., L.H. Kuller, and J. Perper. 1988. An epidemiological study of sudden death at work in an industrial county, 1979-1982. American Journal of Epidemiology 128:806-820.

Robson, R.S. 1984. Flin Flon: A study of company-community relations in a single enterprise community. Urban History Review 12:29-43.

Rockette, H.E. 1977. Cause specific mortality of coal miners. Journal of Occupational Medicine 19: 795-801.

Rosenman, K.D. 1979. Cardiovascular disease and environmental exposure. British Journal of Industrial Medicine 36:85-97.

Ross, M.H., and J. Murray. 2004. Occupational respiratory disease in mining. Occupational Medicine 54:304-310.

Sawchuk, L.A., and S.D.A. Burke. 2000. Mortality in an early Ontario community: Belleville 1876-1885. Urban History Review 29:33-47.

Smith, W.M. 1971. Evaluation of coke oven emissions. Journal of Occupational Medicine 13:69-74.

Steenland, K., C. Burnett, N. Lalich, E. Ward, and J. Hurrell. 2003. Dying for work: The magnitude of US mortality from selected causes of death associated with occupation. American Journal of Industrial Medicine 43:461-468.

Tremblay, G.A. 2007. Historical statistics support a hypothesis linking tuberculosis and air pollution caused by coal. International Journal of Tuberculosis and Lung Disease 11:722-732.

Van Leeuwen, M.H.D., I. Maas, and A. Miles. 2002. HISCO: Historical International Standard Classification of Occupations. Belgium: Leuven University Press.

Wallis, R.S., and J.J. Ellner 1994. Cytokines and tuberculosis. Journal of Lenkocyte Biology 55:676-681.

Wherrett, G.J. 1977. The Miracle of the Empty Beds: A History of Tuberculosis in Canada. Toronto: University of Toronto Press.

Whitbeck, R.H. 1914. A geographical study of Nova Scotia. Bulletin of the American Geographical Society 4(6):413-419. 
Whitfield, J.W. 1954. Individual differences in accident susceptibility among coal miners. Occupational and Environmental Medicine 11:126-139.

Woods, R., and P.R.A. Hinde. 1987. Mortality in Victorian England: Models and patterns Journal of Interdisciplinary History 18:27-54.

Wray, M., M. Miller, J. Gurvey et al. 2008. Leaving Las Vegas: Exposure to Las Vegas and risk of suicide. Social Science and Medicine 67:1882-1888.

Zaridze, D., P. Brennan, J. Boreham, A. Boroda, R. Karpov, A. Lazarev, I. Konobeevskaya, V. Igitov, T. Terechova, P. Boffetta, and R. Peto. 2009. Alcohol and cause-specific mortality in Russia: A retrospective case-control study of 48,557 adult deaths. The Lancet, 373(9682):2201-2214.

Zierler, S., R.A. Danley, and L. Feingold. 1986. Type of disinfectant in drinking water and patterns of mortality in Massachusetts. Environmental Health Perspectives 69:275-279. 